\author{
Visión Electrónica \\ Más que un estado sólido \\ https://doi.org/10.14483/issn.2248-4728
}

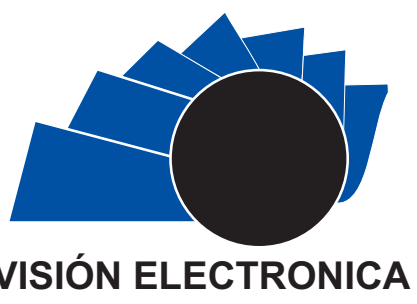

A Research Vision

VISIÓN ELECTRONICA

UNIVERSIDAD DISTRITAL

FRANCISCO JOSÉ DE CALDAS

\title{
Design and simulation of microfluidic device for the detection of HIV
}

\author{
Diseño y simulación de dispositivo de microfluídica para detección de VIH
}

\author{
José Arturo Lagos-Sandoval', Jorge Eduardo Salazar-Zuñiga², \\ Edwing Oswaldo Berdugo-Romero ${ }^{3}$
}

\section{INFORMACIÓN DEL ARTICULO}

Historia del articulo

Enviado: 07/08/2018

Recibido: 16/09/2018

Aceptado: 30/10/2018

\section{Keywords:}

Detection,

Device,

HIV,

Microfluidics,

Reaction.

\section{Palabras clave: \\ Detección \\ Dispositivo \\ HIV \\ Microfluidica \\ Reacción}

\begin{abstract}
This article presents a diagnostic device model, which by using chemical reagents and microfluidics that makes a sort of particle separation and was developed to diagnose an acquired viral immunodeficiency. The device allows to isolate leukocytes and apply a reagent that measures the presence or absence of this virus. The design on the other hand uses tools such as SolidWorks and Autodesk Simulation, which, with the rupture of the membranes and the separation of their components, allows the chemical reaction in the particles and the detection of the virus.
\end{abstract}

Based on the choice of particle analysis and validating the performance of the fluid maintained in the filter stage, which is represented by 5 flow lines, it shows the movement of 5 particles with the same diameter. Additionally, three tests were performed that varied the diameter of the particles to $5 \mu \mathrm{m}, 10$ $\mu \mathrm{m}$ and a larger diameter particle $(15 \mu \mathrm{m})$. The results show that, with a diameter of $5 \mu \mathrm{m}$, the particles move smoothly and the filter can reach the next stage. The particles of $10 \mu \mathrm{m}$ in diameter presented a normal blood flow, however, an obstruction in the particles of $15 \mu \mathrm{m}$ in diameter can be observed.

\section{RESUMEN:}

Este artículo presenta un modelo de dispositivo de diagnóstico, que mediante el uso de reactivos químicos y microfluidos que hace una especie de separación de partículas y se desarrolló para diagnosticar una inmunodeficiencia viral adquirida. El dispositivo permite aislar leucocitos y aplicarles un reactivo que mide la presencia o ausencia de este virus. El diseño por otra parte utiliza herramientas tales como SolidWorks y Autodesk Simulation, que, con la ruptura de las membranas y la separación de sus componentes, permite la reacción química en las partículas y la detección del virus.

Con base en la elección del análisis de partículas y validando el rendimiento del fluido mantenido en la etapa de filtro, el cual está representado por 5 líneas de flujo, muestra el movimiento de 5 partículas con el mismo diámetro. Adicionalmente, se realizaron tres pruebas que variaron el diámetro de las partículas para $5 \mu \mathrm{m}, 10 \mu \mathrm{m}$ y una partícula de mayor diámetro $(15 \mu \mathrm{m})$. Los resultados muestran que, con un diámetro de $5 \mu \mathrm{m}$, las partículas se mueven suavemente y el filtro puede alcanzar la siguiente etapa. Las partículas de $10 \mu \mathrm{m}$ de diámetro presentaron un flujo sanguíneo normal, sin embargo, se puede observar una obstrucción en las partículas de $15 \mu \mathrm{m}$ de diámetro.

\footnotetext{
'Current position: Teacher at Universidad Militar Nueva Granada, Colombia. E-mail: josellagos@unimilitar.edu.co. ORCID: https://orcid.org/0000-0002-9718-2300.

2 Current position: Teacher at Universidad Piloto de Colombia, Colombia. E-mail: jorge-salazar@unipiloto.edu.co. ORCID: https://orcid.org/0000-0002-7000-1346.

${ }^{3}$ Current position: Teacher at Universidad Militar Nueva Granada, Colombia. E-mail: edwing.berdugo@unimilitar.edu.co. ORCID: https://orcid.org/o000-0001-7663-2459. 


\section{Introduction}

The term "Lab on a Chip" (LOAC) or "micro laboratory" is part of a body of knowledge and new techniques in medical science, and in particular within the disease diagnostic procedures from body fluids [1]. It is smart microsystems based microfluidic knowledge and application of micro-and chemical reaction processes, can reduce in size and time own laboratory. The device is durable and easy to use [2].

Thus, such devices have increased its importance in chemical and biotechnological fields as favoring the decrease for reagents used simplify processes and streamline diagnosis in short time. [3]. In Colombia, the research advances Lab on a Chip are scarce or almost nil because the necessary technologies are not sufficiently numerous or inaccessible for development and implementation of these systems. [4]. At the National University of Colombia, Medellin, there is a micro fabrication laboratory and development of MEMS, and in Latin America, has a group of microfluidics and microsystems research in Argentina, which works with the Catholic University of Santa Fe besides the Technological de Monterrey in Mexico with its microfluidic lab. [5].

\section{Methodology}

Between the elements have to be considered, a camera to place the blood sample, a camera for the virus and a camera with the indicator of the presence or absence of the virus. See Figure 1.

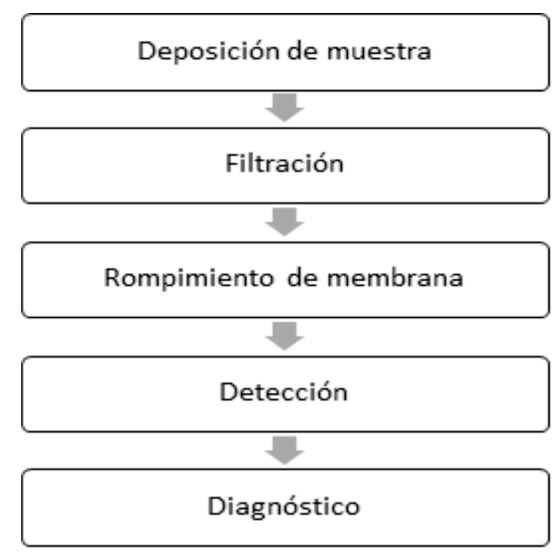

Figure 1. Device Block Diagram. Source: own.

Sample Deposition: Section arranged to locate blood volume to be tested; its extraction is by finger stick. Filtering: selection of specific blood components to prevent the unnecessary use of some cells into analysis, thus ensuring the reliability of the test. Membrane rupture: fragmenting process to cellular dual lipid layer in order to release the viral material that may be contained within the cytoplasm. Detection: stage where the presence of virus is identified by the chemical reaction with the specific viral protein content. Diagnosis: visual signaling result dependent on the presence or absence of virus in the blood sample.

Preliminary Design: The design of a first scheme (Figure 2) using SolidWorks software, with a camera to deposit the sample, followed by a filtration step and an adjacent channel to the deviation of unnecessary material in the waste chamber; followed the virus detection chamber and finally a fluorescence camera indicating the test result.

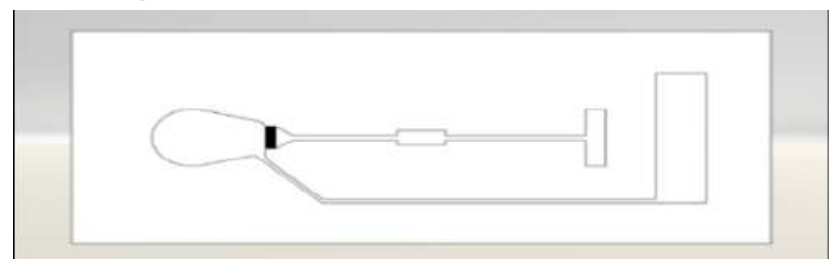

Figure 2. Initial microfluidic system design. Source: own.

Starting with this design was observed the process and were proposed the modifications shown in Figure 3. This new design, retained adjacent channels, the waste chamber and fluorescence camera.

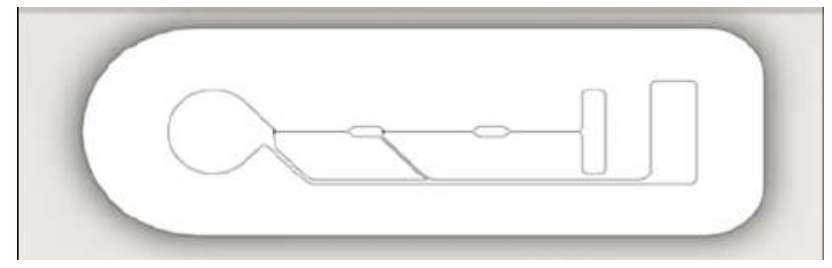

Figure 3. Second microfluidic system design. Source: own.

Based on similar designs of microfluidic systems and information on liquid filtration methods on a small scale, it was decided to remove the drainage adjacent channel, the waste chamber, and attaching a gradient filter (Figure 4) [6]. Consisting of an array of cylinders in the device which gradually increase in size as a function of area of membrane destruction chambers and detection chamber dropped, to reduce the travel time of the bloreducing the gap between them to allow passage of smaller particles, and produce agglomeration or stagnation of the particles not necessary. Also, the od by this zones and an inclination in the base of the device for ensure the presence of a movement due to the weight of the fluid and final design(Figure 5). 


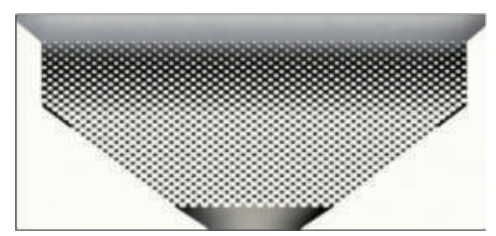

Figure 4. Blood filtration system by gradient. Source: own.

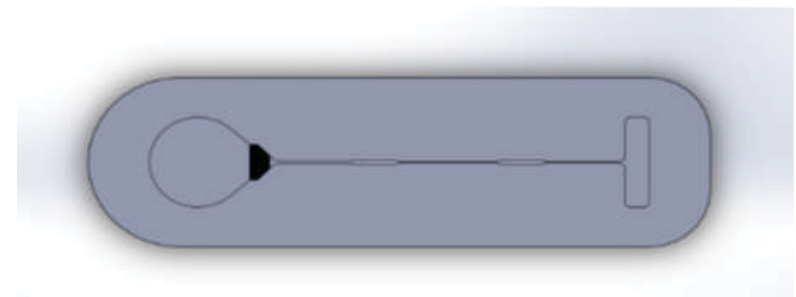

Figure 5. Final design of microfluidic system. Source: own.

The velocity analysis supported by the Navier-Stokes equation (Equation 1), together with the continuity equation (Equation 2), which finally gives us an equation describing the phenomenon of microfluidics, given by Velocity equation (Equation. 3).

$$
\rho \frac{\partial u_{i}}{\partial t}+\rho u_{j} \frac{\partial u_{i}}{\partial x_{j}}=F_{i} \text { Navier }- \text { Stokes }
$$

Here the fluid density, velocity in micro channel and the forces involved are related.

$$
\frac{\partial u_{i}}{\partial x_{i}}=0 \text { Ecuación de Continuidad }
$$

That describes the conservation of momentum. According to Christodoulies, et al (2014) [7], for small Knudsen numbers and considering a negligible gravity force in each microchannel, we get:

$$
\rho \frac{\partial u_{i}}{\partial t}=-\frac{\partial \rho}{\partial x_{i}}+\mu \frac{\partial^{2} u_{i}}{\partial^{2} x_{i}}
$$

\section{Results and analysis}

Using the fluid simulation module of SolidWorks (Flow Simulation), which allows analysis on the behavior of a fluid within a closed conduit, from specifying boundary conditions and the direction of fluid in this space, taking into its features of viscosity and the flow type to represent.

As concerns on software and data, knowing that the blood is fluid to simulate, which has its respective physical properties needed to perform such calculations and generate fluid trajectories a particle level, delivering an automatic report on completion, and such as software, allows to represent, through colors, values speed, pressure, temperature and density, we can show the behavior of the fluid as a function of the variable to be studied. The following was observed: at this stage the flow of blood towards the filter is observed, where in a slowing and stagnation of certain particles occurs, avoiding the transiting towards the channel leading to destruction chamber of membrane, with an increase in the rate at the inlet of said conduit.

At the entrance of fluid towards the chamber fluorescence, observed which extends throughout the area, ensuring that all material spread to the islands of fluorescence, allowing good visualization of the results (Table 1).

\begin{tabular}{|l|r|r|}
\hline \multicolumn{1}{|c|}{ Physical Variable } & \multicolumn{1}{c|}{$\begin{array}{c}\text { Mínimum } \\
\text { Value }\end{array}$} & \multicolumn{1}{c|}{$\begin{array}{c}\text { Maximum } \\
\text { Value }\end{array}$} \\
\hline & 101289.98 & 354691.47 \\
\hline Temperature $[\mathrm{K}]$ & 292.84 & 293.24 \\
\hline Density $\left[\mathrm{kg} / \mathrm{m}^{\wedge} 3\right]$ & 1003.00 & 1003.00 \\
\hline Velocity $[\mathrm{m} / \mathrm{s}]$ & 0 & 7.714 \\
\hline Velocity $(\mathrm{X})[\mathrm{m} / \mathrm{s}]$ & 0.757 & 1.582 \\
\hline Velocity $(\mathrm{Y})[\mathrm{m} / \mathrm{s}]$ & 0.409 & 1.315 \\
\hline Velocity $(\mathrm{Z})[\mathrm{m} / \mathrm{s}]$ & -0.555 & 0.401 \\
\hline
\end{tabular}

Table 1 Results obtained in the report at the end of the simulation with SolidWorks - Flow Simulation. Source: own.

Analysis of early results. We see that the dimensional characteristics of microfluidic system are optimal, and this favors obtaining a diagnosis in less time from a small blood sample. The study of fluid behavior in the simulation module of the SolidWorks Software (Flow simulation), allows us to observe important features regarding the speed and pressure ranges that are available, taking into account that this is an ideal environment, under stable environmental characteristics. It is observed that the initial design meets the standards required by the device relative to their physical conditions for blood transport, however, adjustments are made to the design to ensure that chemical reactions occurs, increasing the width of the fluid transportation conduits. [8]

According to some limitations in calculations, of Solid work software, is decide to try simulating with Autodesk $₫$ Inventor ${ }^{\circledR}$ and Autodesk Simulation CFD; which do not impose any disadvantage to perform simulations and calculations. 
Is imported the Model previously built in SolidWorks to a simulation of blood flow in Autodesk ${ }^{\circledR}$ Simulation CFD, (Figure 6) under initial identical conditions and limits, as the set used for SolidWorks to verify the validity of the process the both programs; the values of interest rate on the $\mathrm{X}$-axis for SolidWorks, and $\mathrm{Z}$ for AutodeskSimulation- $(\operatorname{Vmax}=1548.64 \mathrm{~mm} / \mathrm{s}, \mathrm{Vmin}=$ $847.3 \mathrm{~mm} / \mathrm{s}$ ) are close to a large extent to the results thrown by SolidWorks in the first test (Vmax = $1582 \mathrm{~mm} / \mathrm{s}$, Vmin $=757 \mathrm{~mm} / \mathrm{s}$ ). According eq. 3 .

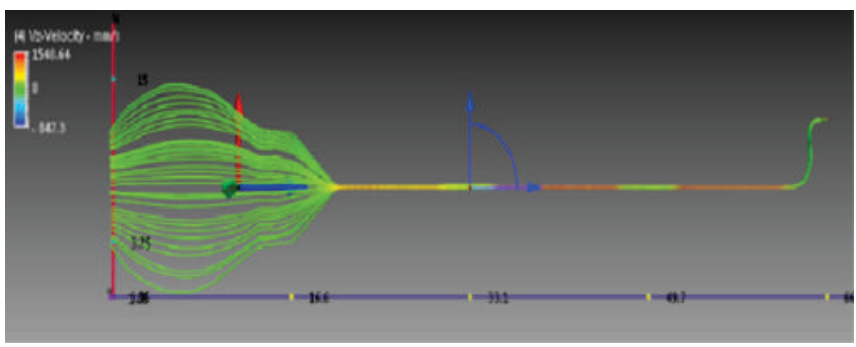

Figure 6. Behavior and velocity of fluid simulated on AutodeskSimulation CFD. Source: own.

Various aspects of the structure of the microfluidic device considered, such: design sample deposition chamber, width and shape of channels and reaction chambers design, and using the Autodesk $\mathbb{R}$ Inventor software, was modified the prior design of device (Figure 7) with the necessary transformations.

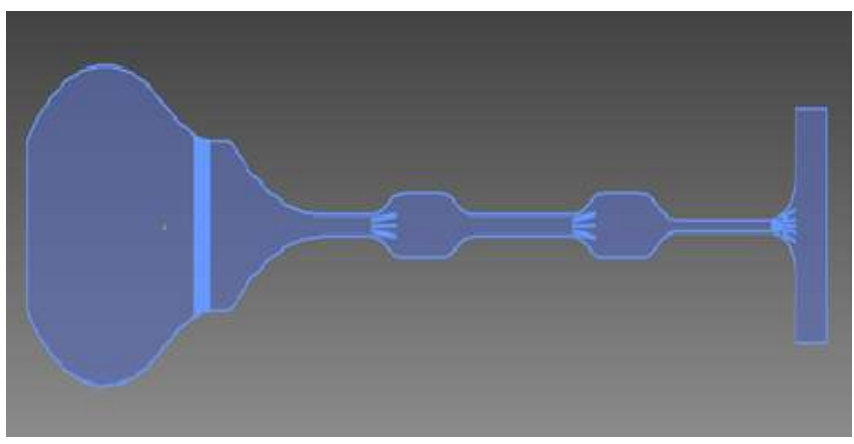

Figure 7. Modified microfluidic system model in Autodesk Inventor. Source: own.

Simulating the behavior of the fluid within the new model just to assess the validity of the changes made to the initial design and demonstrate the trajectories, velocity values and pressure that can generated using the display option of components of the variables by cuts or planes (Figure 8) and the analysis of particle behavior.

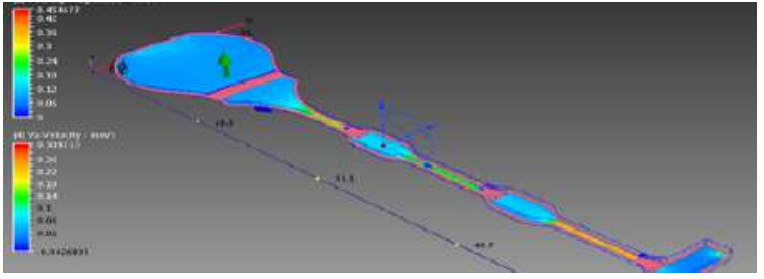

Figure 8. Viewing the results of axial cutting speed. Source: own.

The boundary conditions of the system are established, there, is configured the fluid inlet to an average value of about 5 drops of blood $(0.113 \mathrm{~mL})$ capacity, working with an environment temperature value of $19.5^{\circ} \mathrm{C}$, setting the calculation results for 200 iterations. The results indicate that the values of fluid velocity within the device are significantly lower than those presented in the initial design, reaching a maximum speed on the $Z$ axis (axis of interest) of $0.309213 \mathrm{~mm} / \mathrm{s}$. (Figure 9) [9].

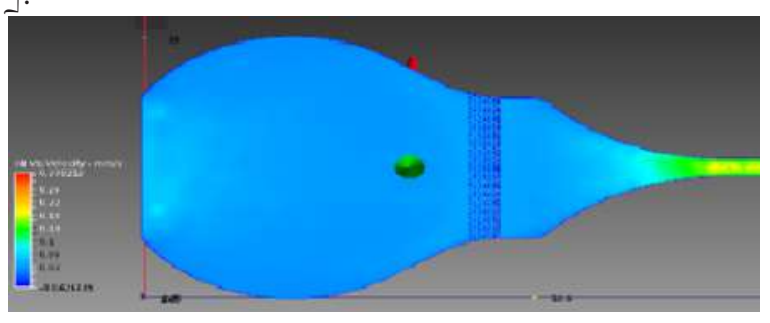

Figure 9. Fluid velocity in the sample deposition chamber, in filter and filter output. Source: own.

Similarly, Autodesk ${ }^{\circledR}$ Simulation CFD has the option of calculating the residence time of any particle of the fluid; this refers to the time it takes the particle from the start point to the end point of the route, across to the selection of any point on any of the planes or axes speed (transverse, longitudinal or axial). In a first analysis, the axial plane is established, and selected four points (4) near the edge of the inlet fluid for simulation.

When you run the process "Add Trace List", the software immediately draws the trajectory of the points and generates a simulation of fluid motion in the system; similarly, the values of residence time are generated, in seconds, for each simulated particle (Figure 10), having a minimum residence time of 1376.5 seconds, equivalents to 22.941 minutes.

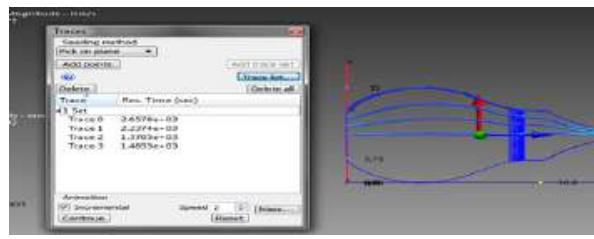

Figure 10. Residence times for each selected particle. Source: own. 
Regarding the choice, of particle analysis (Autodesk $®$ Simulation CFD), was validated the behavior of the fluid in the filtering stage, represented by 5 flux lines, showing the five particle motion of equal diameter; for this process, three tests were performed by varying the diameter as well: first, diameter less than $10 \mu \mathrm{m}$ particle ( $5 \mu \mathrm{m})$, second particle diameter equal to $10 \mu \mathrm{m}$ and finally increased to more of $10 \mu \mathrm{m}$ diameter $(15 \mu \mathrm{m})$ particle. [10].

The results show that the diameter of $5 \mu \mathrm{m}$ the particles travel smoothly and the filter may reach the next stage (Figure 11). Similarity, for particles of diameter $10 \mu \mathrm{m}$, normal blood flow in the filtering stage is presented, however it can be observed the obstruction, of the central trajectory (Figure 12), and finally, the simulation of the particles $15 \mu \mathrm{m}$ diameter only shows two of the particles represented affected by the filter and are trapped; by visualizing the trajectories with Ribbons, we can get an idea of the changes presented in the motion of the particles, when they reach to the filter, change their path of "horizontal" to "vertical" to continue to the next step (Figure 13).

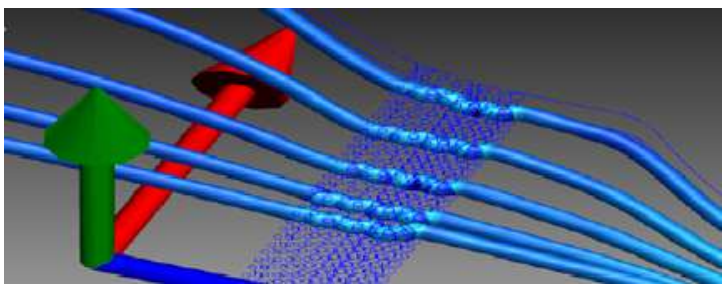

Figure 11. Behavior of the particles of $5 \mu \mathrm{m}$ to traverse the filter. Source: own.

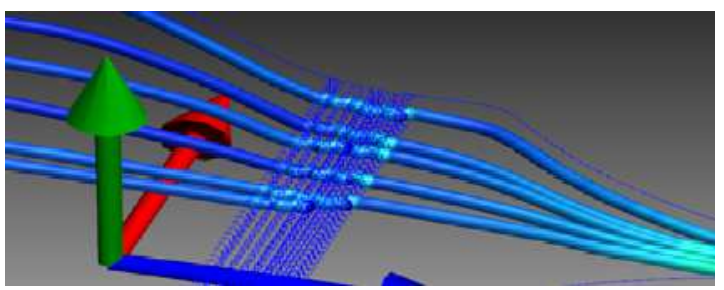

Figure 12. Behavior of the particles of $10 \mu \mathrm{m}$ to traverse the filter. Source: own.

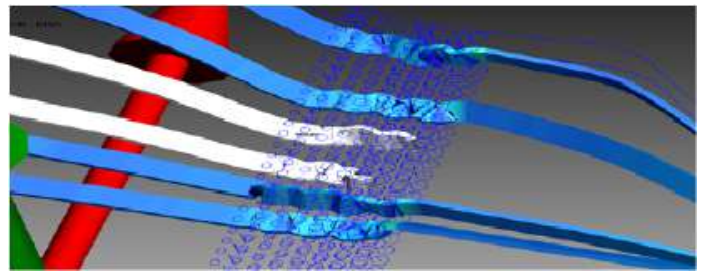

Figure 13. Behavior of the particles of $15 \mu \mathrm{m}$ to traverse the filter. Source: own.
Based on the simulated process and results, adjustments were made to obtain the design or final model (Figure 14), this has a hole for the placement of the blood sample to be analyzed and a band in the bottom, which acts as a window towards the fluorescence chamber and is responsible of indicate the result of the presence or absence of the virus; the other components are internal to the device.

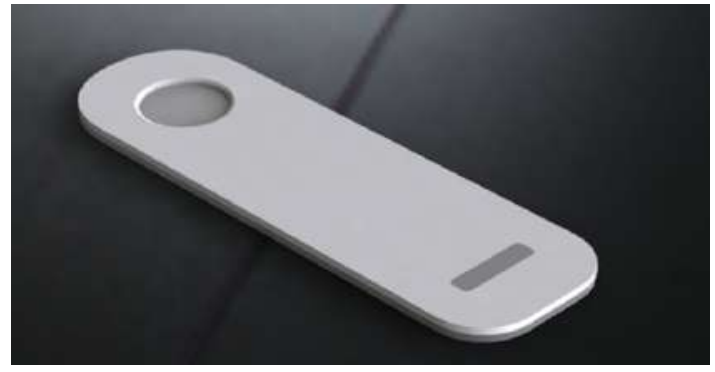

Figure 14. Industrial design of the final product. Source: own.

\section{Conclusions}

The proposed microfluidic design facilitates sample handling blood and its cellular components, where from the structure of the ducts can establish a residence time of the particles (blood) within the relatively short journey to favor the obtaining quickly results.

The filtering step is arranged such that the T cells can cross towards the following stages and as the blood cells are the most affected by the human immunodeficiency virus, then increases the probability of finding viral material inside these cells.

The result of the analysis will depend on the biochemical reaction triggered by the presence of the proteins p24, p32 and gp41; they are also used in Western Blot tests; the blood particles and of the antigens which are located in the detection chamber.

\section{References}

[1] C. Yu Chan, V. N. Goral, M. E. Rosa, T. Jun Huang and P. Yuen, "A polystyrene-based microfluidic device with three-dimensional interconnected microporous walls for perfusion cell culture", Biomicrofluidics, vol. 8, no. 4, 2014. https://doi.org/10.1063/1.4894409 
[2] C. Chi, et al., "Microfluidics-based diagnostics of infectious diseases in the developing world", Nature Medicine, vol. 17, no. 8, 2011, pp. 1015-1019.

https://doi.org/10.1038/nm.2408.

[3] Y. Ghallab and W. Badawy, "Lab-on-a-chip Techniques, Circuits, and Biomedical Aplications", United States: Artech Haouse, 2010.

[4] G. Binyamin, T. Boone, H. Lackritz, A. Ricco, A. Sassi and S. Williams, "Plastic microfluidic devices: electrokinetic manipulations, life science applications, and production technologies", Lab on a Chip, 2003, pp. 83-111. https://doi.org/10.1016/B978-0444511003/50005-X.

[5] H. Joenssonand H. Andersson, "Droplet microfluidics-a tool for protein engineering and analysis", Lab on a Chip, no. 24, 2011. https://doi.org/10.1039/c1lc90102h.

[6] N. Nguyen, "Fundamentals and Applications of Microfluidics", Boston: Artech House, 2002.

[7] P. Christodoulies, G. Florides, K. Kalli, C. Koutsides, L. Lazari, M. Komodromos and F. Dias, "Microfluidics in microstructure optical fibers: heat flux and pressure-driven and other flows", Procedia IUTAM, vol. 11, 2014, pp. 2333.

[8] F. Banica, "Chemical Sensors and Biosensors Fundamentals Applicationes”, John Wiley \& Sons, Ltd, 2012. https://doi.org/10.1002/9781118354162.

[9] A. Avila and Y. Mora, "Designing and simulating a nitinol-based micro ejector", Revista Ingeniería e Investigación, vol. 32, no. 1, 2012, pp. 42-47.

[10] J. Ducrée, "Next-generation microfluidic labon-a-chip platforms for point-of-care diagnostics and systems biology", Procedia Chemistry, vol. 1, no. 1, 2009, pp. 517-520. https://doi.org/10.1016/j.proche.2009.07. $\underline{129 .}$. 